\title{
FORMATION OF SPATIAL THINKING IN GEOGRAPHY TRAINING
}

DOI: https://doi.org/10.18509/GBP210603g

\section{Evdokia Gergova}

Sofia University "St. Kliment Ohridski", Faculty of Geology and Geography, Bulgaria

\begin{abstract}
The formation of students' spatial thinking is defined as an absolute value of geographical education. This is related on the one hand to the specifics of geographical science, and on the other - to the essence of spatial thinking. The contribution of geography education comes from geography as a science. It analyzes the numerous spatial relationships of the earth's surface to achieve a scientific understanding of the importance of space for human behavior - a kind of "geographical wisdom". This analysis underlies many human decisions. Concrete solutions and their spatial expression show that people perceive space differently and as a consequence receive different spatial information about the same objects or situations. This is determined by their needs and their ability to perceive the environment, to make adequate decisions, to implement them. The concept dominates in modern geographical education. According to it, the student fully acquires geographical knowledge only when it acquires meaning for him, when he becomes involved in what is being studied.

The type of intellectual activity that arises in the practical need for orientation in space is defined as spatial thinking. Given the specifics of geographical knowledge and the nature of the type of thinking that manifests itself in it, this report defines the place of spatial thinking in the context of the leading ideas in the strategy of geographical education in high school in Bulgaria.
\end{abstract}

Keywords: geographical education, spatial thinking, geography training, strategy of geographical education

\section{INTRODUCTION}

In the context of the learning content

According to the interpretation of the place of spatial thinking in geographical education in secondary school, which is made in this article, it is necessary to first consider the content aspect. The essential characteristics of the geographical content are the basis for formulating the goals of the geography education. The educational content, in the processing of which spatial thinking is formed and developed, is determined by the answers to the basic questions for geography: "Where, what is it there, and why is it exactly there, where it could be?" [3], [8]. These answers are related to the attributes of the geographical object - spatial location; spatial structure; spatial process [1].

Therefore, in the modern strategy of geographical education this approach to the study of the geographical object could be the basis for the selection and structuring of the educational content at macro and micro level and be reflected in the curricula and textbooks [7]. 
In the context of the goals of geographical education

The main goal of geographical education in high school "to form the foundations of geographical culture in students, as part of their general culture - for reasonable activity in the geographical space." [6], [2], [3] can be operationalized in a behavioral aspect in the context of spatial thinking. At the same time, the goals will be consistent with the content constructs, which are the content of both spatial thinking and geographical education. This needs to be specified in the curriculum. An example of operationalizing the goal is shown in the table:

Table 1. Example of operationalizing the goal

\begin{tabular}{|l|l|}
\hline Skills & Relationships \\
\hline $\begin{array}{l}\text { To determine the absolute and relative } \\
\text { location of an object; }\end{array}$ & $\begin{array}{l}\text { The young person participates in different social roles and } \\
\text { in different spatial relationships; } \\
\text { To understand one's own participation in natural and } \\
\text { For analysis and interpretation of the spatial } \\
\text { structure of the object; }\end{array}$ \\
$\begin{array}{l}\text { For analysis and explanation of the } \\
\text { social situations; } \\
\text { processes, as a result of which such a } \\
\text { structure is formed, exactly in a certain } \\
\text { place. }\end{array}$ & $\begin{array}{l}\text { issues in space; } \\
\text { To conduct individual or team basic geographical research } \\
\text { in order to obtain and apply information. }\end{array}$ \\
\hline
\end{tabular}

In the context of the learning process

The spatial nature of the geographical content, the essence of spatial thinking - a "tool" for mastering this content, the behavioral emphasis in the goals of geographical education give grounds for specifying some requirements for the process of teaching geography to develop qualities of spatial thinking. In accordance with the behavioral orientation of the goals, it is natural for the student to be a subject of learning. It manifests itself as such in the process of solving problems.

In current teaching practice, the teacher intuitively creates such tasks when it is necessary to compensate for their absence in the textbook. In this sense, the development of spatial thinking is not fully realized for either the teacher or the student. The purposeful development of spatial thinking can be achieved by carrying out a problematic type of training through a system of tasks designed in the textbook.

What are the features of such a system of tasks? The system is composed of tasks in which the content of spatial thinking is designed [9]. Two types of activities can be understood as the content of spatial thinking:

- To create images for the spatial attributes of the geographical object on the basis of different types of visualization (natural-material models, graphic and cartographic images);

- For operation in spatial images, ie. their inclusion in various connections and relationships in accordance with the condition of the task.

The system will have the property "integrity" if it contains tasks both for creating images and for operating with images of the three attributes of the geographical object [1].

The connections between the tasks, ie. the structure of the system is determined by:

- the sequence in which the types of visualization are used (from object, threedimensional images, in which the point of orientation is fixed in the subject itself to graphic and cartographic, two-dimensional images, at an arbitrarily chosen point of orientation);

- the gradual development of the qualities of spatial thinking - independence in the analysis and interpretation of situations in space; speed and criticalness in decision making; ability to select an appropriate image. 
Table 2. Exemplary research objectives for diagnosing the condition of the problem of spatial thinking in three aspects

\begin{tabular}{|l|l|}
\hline$№$ & Example goals \\
\hline 1 & As a design in the teaching documentation of geography \\
\hline 2 & As a competence, ability and readiness of the geography teacher to develop this type of thinking \\
\hline 3 & As qualities of students' spatial thinking - a result of teaching geography \\
\hline
\end{tabular}

Table 3. Example methodology for studying the state of the problem of spatial thinking

\begin{tabular}{|c|c|c|c|c|}
\hline № object & Subject & Method & Tool & $\begin{array}{l}\text { Presentation of } \\
\text { the result }\end{array}$ \\
\hline $\begin{array}{l}\text { 1. Training } \\
\text { documentation } \\
\text { - a book for the } \\
\text { teacher }\end{array}$ & $\begin{array}{l}\text { Theoretical formulations for } \\
\text { goal-effective, content and } \\
\text { procedural aspect of the } \\
\text { problem for development of } \\
\text { spatial thinking in teaching } \\
\text { geography }\end{array}$ & analysis & & \\
\hline -textbook & $\begin{array}{l}\text { Tasks and visual images in } \\
\text { which technology for the } \\
\text { development of spatial } \\
\text { thinking is designed }\end{array}$ & $\begin{array}{l}\text { content } \\
\text { analysis }\end{array}$ & table & table \\
\hline 2. Teachers & $\begin{array}{l}\text { Competence and ability to } \\
\text { develop spatial thinkin }\end{array}$ & surveying & survey & graphic images \\
\hline 3. Students & $\begin{array}{l}\text { The qualities of spatial } \\
\text { thinking - a result of teaching } \\
\text { geography }\end{array}$ & test & test paper & $\begin{array}{l}\text { Profile } 1 \\
\text { Profile } 2\end{array}$ \\
\hline
\end{tabular}

The system of tasks will have the feature of "structure" if the tasks involve the use of different types of visualization in a certain sequence and if in their conditions the development of the indicated qualities of spatial thinking is purposefully designed.

It is possible to design the tasks so that they are used in all moments of the macrostructure of the lesson - when announcing and motivating the topic, when developing the new curriculum, when consolidating, when controlling [4], [5]. This means that the approach and criteria for constructing the learning content at the level of learning material to coincide with those for formulating the tasks of the system. In this case, the task system will have the feature "functionality" [9].

In accordance with the presented theoretical statements about the place of spatial thinking in geographical education, specific research can be done to establish the state of the problem. Here we offer sample goals and methodology for such a study

Such a methodology can be fully used only in compliance with relevant criteria and indicators for spatial thinking. Such are presented in Table 4. 
Table 4. Exemplary criteria and indicators for the development of spatial thinking

\begin{tabular}{|l|l|}
\hline Criteria & Indicators \\
\hline 1. Ability to create images & 1.1. Completeness of the image for ... \\
& $1.1 .1 \ldots$ composition and structure of the site \\
& $1.1 .2 \ldots$ location of an object \\
& $1.1 .3 \ldots$ the processes as a result of which exactly this structure and \\
& exactly this place is formed \\
& 1.2. Width of image creation for ... \\
& $1.2 .1 \ldots$ the composition and structure of an object \\
& $1.2 .2 \ldots$ the processes as a result of which exactly this structure and \\
& exactly this place is formed \\
\hline 2. Ability to operate with & 2.1. Width of image operation \\
& 2.1 .1 . Changing the spatial location \\
& 2.1 .1 .1 . Ability to select an object for orientation \\
& 2.1 .1 .2 . Application of regularities \\
& 2.1 .2$. Change in the spatial structure \\
& 2.1 .2 .1 . Application of knowledge of general concepts \\
& 2.1 .2 .2 . Application of knowledge of regularities \\
& 2.1 .3 . Changing the spatial location \\
& 2.1 .3 .1 . Ability to select an object for orientation \\
& 2.1 .3 .2 . Application of knowledge of general concepts \\
& 2.1 .3 .3 . Application of knowledge of regularities \\
& 2.1 .3 .4 . Ability to present information about location and structure \\
& through different types of visualization \\
\hline
\end{tabular}

\section{CONCLUSION}

In the teaching of geography a specific type of thinking is developed - spatial thinking. The concretization of the target, content and procedural aspects of the development of this type of thinking in the context of the strategy of geographical education in the secondary school in Bulgaria gives an opportunity for: purposeful diagnosis of the state of this problem; constructive interpretation of research results; construction of technology for the development of this specific type of thinking for teaching geography, and subsequently - its design by the teacher and the student.

\section{REFERENCES}

[1] Ангелова-Ганчева, Д. Някои аспекти на пространственото мислене в контекста на нова стратегия на географското образование в средното училище. Доклади от Международна научна конференция. Стара Загора, 1995, 106-118

[2] Василева, М., Методика на обучението по география - едно по-широко разбиране за методите на обучение, УИ "Св. Климент Охридски", ISBN 978-954-07-4355-4, София, $2018 \mathrm{a}$

[3] Василева, М., Актуални въпроси на съвременната дидактика на географията, МЕЛАНИ, ISBN 978-954-92917-9-7, София 20186.

[4] Василева, М., Идеи за усъвършенстване на планирането и структурирането на урока по география - поглед към съвременната немска дидактика на географията, Годишник на СУ, том: География, брой: 104, 2012

[5] Василева, М., Н. Маринова, Идеи за усъвършенстване на структурата на урока по география, География 21, брой: 2, 2011

[6] Гайтанджиева, Р. Стратегия на географското образование в СОУ при новите реалности, Анубис. С. 2000

[7] Цанкова, Л. Ръководство по дидактика на географията. УИ. С. 2005 
[8] Could, P. Spatial organization. The geographers view of the world. London. 1972

[9] Vasileva, M., Naydenov, K., Geography educational system - analysis from the social management positions, International Scientific Conference GEOBALCANICA 2018 